\title{
A pesquisa histórica no Itamaraty
}

\author{
PIO PENNA FILHO*
}

\begin{abstract}
“...restabelecer a Seção do Arquivo, dando-lhe o desenvolvimento necessário, porque esse é o arsenal em que o Ministro e os empregados inteligentes e habilitados encontrarão as armas de discussão e combate". ${ }^{1}$
\end{abstract}

\section{O Arquivo}

O Arquivo Histórico do Itamaraty apresenta vasto e rico acervo documental que registra múltiplos aspectos da história do Brasil, com ênfase, naturalmente, nos assuntos que dizem respeito às relações internacionais do país. Dividido em duas unidades, parte do seu acervo está localizada no Rio de Janeiro e a outra, em Brasília.

No Rio de Janeiro, encontram-se as coleções documentais mais antigas, que vão dos papéis colecionados do início do século XIX até os anos 1950. Existem, porém, documentos ainda mais antigos que remontam à época do Brasil-colônia. Encontram-se, também naquela unidade, as coleções de arquivos particulares adquiridos por compra ou doação, como o arquivo pessoal do Barão do Rio Branco. Localizado no Palácio Itamaraty, o acervo do Arquivo Histórico no Rio de Janeiro está totalmente liberado à consulta dos pesquisadores, uma vez que todo ele está disponível ao público na forma da legislação em vigor. Constitui-se, com efeito, em um arquivo de "fundo fechado", haja vista que a documentação que possa eventualmente remeter a assuntos em andamento da Chancelaria brasileira foi transferida para Brasília.

A partir de 1972, com a transferência definitiva do Ministério das Relações Exteriores para a nova capital, parte desta documentação foi deslocada para a nova capital em decorrência das próprias necessidades do serviço diplomático. Desta forma, juntamente com o Ministério, foi deslocada para Brasília a documentação mais recente do Itamaraty. $\mathrm{O}$ acervo transferido teve como marco inicial o ano de 1960; no entanto, é possível encontrar, em Brasília, documentos secretos e confidenciais que remontam a 1947 (eventualmente, pode-se achar nos 
maços documentos anteriores a essa data). Com relação aos ostensivos e reservados, estão em Brasília os produzidos a partir de 1960 (ocasionalmente, o pesquisador poderá encontrar documentos relativos a 1959, mas como exceção à regra).

O acervo documental do Ministério das Relações Exteriores está dividido em cinco categorias no que diz respeito à natureza e ao grau de sigilo do assunto da documentação: a) secreto-exclusivo, ${ }^{2}$ b) secreto, c) confidencial, d) reservado, e e) ostensivo. Os documentos classificados como secretos-exclusivos obedecem a um período de restrição de 30 anos, os secretos seguem a regra de restrição à consulta de 20 anos, os confidenciais, de 10 anos, os reservados, de 5 anos e os ostensivos estão virtualmente liberados. Apesar de constar na legislação com certa restrição, os documentos classificados como reservados praticamente seguem a regra dos ostensivos e estão, pois, liberados, aparecendo nos volumes organizados juntamente com estes últimos. ${ }^{3}$

Menção especial deve ser feita aos documentos classificados como secretos-exclusivos. Os papéis assim classificados contêm assuntos que requerem alto grau de sigilo e diferenciam-se dos secretos pelo fato de seu conteúdo ser de conhecimento exclusivo do destinatário. Via de regra, são expedidos diretamente pelo Secretário Geral ou pelo Ministro de Estado para os Embaixadores em postos no exterior. Seu uso - e consequentemente seu volume - é bastante reduzido.

Além da classificação supracitada, os documentos diplomáticos também se distribuem de maneira diversa. Particularmente interessantes para a pesquisa histórica são: 1) os Ofícios recebidos pela Chancelaria - que são remetidos pelas Embaixadas, Consulados e Representações brasileiras no exterior; 2) os Despachos (ou ofícios expedidos) emitidos pela Chancelaria para as Missões diplomáticas no exterior; 3) os Telegramas e as Cartas-telegramas expedidos e recebidos tanto pela Chancelaria quanto pelas Embaixadas e Missões junto a Organismos Internacionais (como a ONU, a OEA etc.); 4) as Notas trocadas entre a Chancelaria brasileira e as Missões estrangeiras credenciadas no Brasil - e no exterior, entre as Missões diplomáticas brasileiras e o Governo local; 5) as Instruções para os Chefes de Missão Diplomática no exterior; 6) Instruções para as delegações brasileiras nos foros internacionais; 7) a série de Memorandos, Pareceres e Requerimentos, que se constitui em uma rica e interessantíssima documentação interna, contemplando assuntos os mais variados, como questões políticas, econômicas, assuntos em andamento, pareceres jurídicos sobre temas diversos e requerimentos internos; e 8) os Avisos, correspondência trocada entre Ministros de Estado e órgãos subordinados à Presidência da República. ${ }^{4}$

Nos Memorandos, encontram-se as discussões internas, nas variadas instâncias do Ministério das Relações Exteriores, que levam às decisões na política externa brasileira apresentando as questões mais sensíveis que foram tratadas no 
âmbito do MRE. ${ }^{5}$ Os memorandos constituem uma excelente demonstração do processo decisório interno do Itamaraty, contendo assuntos meramente administrativos ou pontos altamente sensíveis, como a análise política da conjuntura internacional, avaliações sobre países e assuntos correntes da agenda internacional ou planejamento para o relacionamento bilateral. Em alguns casos, é possível acompanhar toda a trajetória de um determinado assunto, desde a elaboração da questão eventualmente tratada por um Secretário e enviada ao seu superior, o parecer e a recomendação deste até o visto e a decisão final do Ministro de Estado.

Além da organização dos documentos estabelecida através de sua tipologia, elencados pelo nome da capital do país e pelo tipo de documento, se ofício expedido, recebido, telegrama etc. (por exemplo: Buenos Aires, Ofícios Expedidos, Secreto), há ainda uma massa documental colecionada em pastas classificadas ("pastas por ordem de classificação") de acordo com o assunto a que se refere a documentação. A maior parte desse acervo obedece a um sistema decimal de classificação, segundo o qual os temas de interesse do Ministério das Relações Exteriores foram divididos em dez classes:

Classe 0 - Assistência Judiciária Internacional;

Classe 1 - Congressos e Conferências Internacionais;

Classe 2 - Limites;

Classe 3 - Ministério das Relações Exteriores;

Classe 4 - Miscelânea;

Classe 5 - Negócios Internos do Brasil;

Classe 6 - Negócios Internos dos Estados Estrangeiros;

Classe 7 - Proteção de Interesses e Reclamações;

Classe 8 - Relações Econômicas e Comerciais;

Classe 9 - Relações Políticas dos Estados.

Neste tipo de classificação, já substituída pelo Itamaraty, porém sem alterar a organização do acervo previamente classificado, os assuntos estão dispostos em uma ordem sistemática, indo do geral ao particular, de forma que as matérias afins estão agrupadas em uma seqüência que permite a associação dos temas correlatos. Geralmente, as pastas se encontram organizadas por assuntos e por países, apresentando em sua parte superior o número da classificação decimal e o assunto, o que facilita a identificação do tema contemplado em uma determinada pasta. $^{6}$

Classificados como secretos ou confidenciais, os documentos dessas pastas contêm assuntos diversos e estão agrupados seguindo uma unidade temática, como por exemplo: Países (África do Sul, Bolívia, Argentina, França etc.), Fronteiras, Produtos de base, Assuntos militares, Guerras, Terras, Águas, Imprensa, Possessões, Relações Políticas e Diplomáticas, Sigilo (guarda da correspondência), Chefes de Missões Diplomáticas, Politica Internacional, 
Criptografia Mecânica, Situação Política Interna, "Agrément", Material Bélico, Raça, "Apartheid", Águas Fluviais, Imprensa, Comunismo, entre outros. As pastas por ordem de classificação abrigam variada gama de documentos, principalmente cópias de telegramas e ofícios recebidos pela Chancelaria das Missões diplomáticas no exterior. Na verdade, trata-se de uma coleção de cópias de documentos selecionados que foram organizados com o objetivo de facilitar a pesquisa em assuntos de especial interesse do Itamaraty. Além disso, pode-se localizar, nessas pastas, ofícios expedidos pela Chancelaria, dependendo muito do assunto e do interesse despertado pelo tema à época de sua produção. É possível encontrar também documentos de especial interesse para os pesquisadores, tais como relatórios e ofícios recebidos de outros órgãos governamentais, como Presidência da República, Ministérios Militares e Civis. Todavia, faz-se necessário ressaltar que a documentação supramencionada, muito embora esteja organizada em pastas de fácil manuseio, encontra-se dispersa nas dependências do Arquivo em Brasília, permanecendo praticamente fora do alcance dos pesquisadores.

A partir de novembro de 1985, foi instituída, no âmbito do Itamaraty, nova forma de classificação dos documentos, o Sistema Thesaurus. Diferentemente do modelo anterior que, como visto, organizava os documentos de forma decimal, e em que os temas de interesse estavam divididos em dez classes, o novo método mais flexível e visando à modernização da sistemática de classificação dos documentos e à informatização administrativa - consiste no "emprego de um conjunto de quatro letras (que representa o assunto) e o código do país, países ou organismos, ao qual se refere o assunto. A primeira das quatro letras representa o assunto principal, e as outras três, o assunto secundário. No caso específico do MRE, fez-se uma divisão do Ministério em categorias de assuntos principais, sendo cada uma representada pela primeira letra do Sistema". ${ }^{7}$

O Sistema Thesaurus também operou modificações no que diz respeito à classificação dos documentos, antes dispostos em dez classes generalizantes. Com a adoção do novo sistema, os assuntos foram divididos em quinze categorias ou códigos de assuntos. Neste sentido, cada categoria é composta por quatro letras, em um sistema em que a primeira letra corresponde ao assunto geral e as três seguintes são indicativas do tema específico correspondente. Desta maneira, os códigos possuem abrangência satisfatória, o que torna mais fácil a memorização e familiarização do objeto a ser pesquisado por parte dos usuários. ${ }^{8}$

Assim, no Itamaraty a indexação pelo Sistema Thesaurus classifica os assuntos básicos, adotando a seguinte estrutura:

1) A - Assuntos de Administração do MRE;

2) C - Assuntos Consulares;

3) D - Assuntos de Cerimonial e Corpo Diplomático;

4) E - Assuntos Econômicos;

5) G-Gestões, Reuniões, Visitas Governamentais; 
6) I - Imprensa e outros meios de comunicação;

7) J - Assuntos Jurídicos;

8) K - Assuntos Culturais;

9) M - Assuntos do Mar, Antártida e Espaço Exterior;

10) P - Assuntos Políticos;

11) $\mathrm{Q}$ - Controle Interno;

12) $\mathrm{S}$ - Assuntos Sociais;

13) W - Meio Ambiente;

14) $X$ - Comércio Internacional;

15) MBAS - Maço Básico de País ou de Assunto.

Todavia, como exposto mais acima, o Sistema Thesaurus só foi adotado no final de 1985, o que significa que os pesquisadores só irão deparar-se com documentos liberados incluídos nesta classificação no período de 1986 a 1989 para os confidenciais e na totalidade para os ostensivos. Isto demonstra, portanto, a importância de se conhecer a antiga classificação, que, na verdade, é a que rege a maior parte dos documentos já liberados para consulta. Sobretudo se considerarmos que os documentos ostensivos geralmente são agrupados em maços ou pastas seguindo um arranjo por país e por ano, ou seja, não entram neste tipo de classificação.

Do ponto de vista administrativo e organizacional, a Seção de Arquivo Histórico (SAH) está subordinada à Divisão de Comunicações e Arquivo (DCA) que, por sua vez, faz parte do Departamento de Comunicações e Documentação (DCD). Este, na estrutura administrativa do Itamaraty, subordina-se à Subsecretaria Geral do Serviço Exterior, vinculada à Secretaria Geral.

No caso do Arquivo Histórico, localizado no Rio de Janeiro, este subordinase diretamente ao Escritório Regional no Rio de Janeiro (ERERIO), sendo, portanto, desvinculado da estrutura referida para a Seção do Arquivo Histórico localizado em Brasília. É interessante notar que, muito embora ambos tenham função similar - a guarda de documentos históricos produzidos pela Chancelaria brasileira -, são unidades administrativas independentes, sem vínculos diretos. Ainda com relação ao Rio de Janeiro, cite-se o caso de outras unidades afins ao Arquivo, quais sejam: a Mapoteca, a Biblioteca e o Museu Histórico e Diplomático.

Isto evidencia que há o entendimento, em certas instâncias do Itamaraty, de que a parte estritamente considerada histórica para o Ministério está localizada no Rio de Janeiro. Corroborando esta tese, temos a Comissão de Estudos de História Diplomática (CEHD), que é a responsável pela desclassificação ${ }^{9}$ de documentos e análise de solicitações de pesquisa, que funciona no Rio de Janeiro. Com efeito, trata-se de uma interpretação bastante natural e lógica, haja vista que o acervo do Arquivo Histórico no Rio é aquele que contém a documentação mais antiga e já totalmente liberada para consulta. ${ }^{10}$ 


\section{Legislação}

Nas últimas décadas, houve poucas mudanças, porém, substanciais, na política nacional de arquivos e na legislação de acesso aos documentos históricos. O marco renovador, como não poderia deixar de ser, foi o processo de redemocratização do país que culminou com a Constituição de 1988.

Na verdade, o acesso ao Arquivo sempre foi um grande problema para os pesquisadores ${ }^{11}$ que, via de regra, recorriam a fontes no exterior para escrever capítulos da história nacional. Nos últimos trinta anos, o que sofreu alteração como desdobramento do Golpe de Estado de 1964 foi a classificação dos documentos da Chancelaria brasileira que passou a ser feita de maneira mais rígida, inovando-se inclusive com uma classificação que não existia anteriormente: a dos documentos secretos-exclusivos. Em certa medida, a natureza do regime, o seu projeto de transformar o Brasil em potência e suas conexões com o exterior propiciaram a produção de uma série de documentos que continham assuntos classificados como sigilosos e que diziam respeito direto à segurança nacional mas, principalmente, à segurança do próprio regime.

Neste sentido, houve, nos "anos de chumbo", uma intensa produção de documentos que foram imediatamente classificados como secretos, ou secretosexclusivos, dos quais muitos só poderiam existir em um regime de exceção. A leitura da documentação produzida pelo Itamaraty no período posterior a 1964 indica, por exemplo, forte retomada da preocupação com a "ameaça comunista" ao Brasil. A tentativa de livrar a sociedade brasileira do "mal comunista", depurandoa com a eliminação física ou via expurgos, atingiu praticamente todas as instituições, inclusive, naturalmente, o Itamaraty. Existe, por exemplo, uma série de inquéritos internos que objetivavam esclarecer posturas ideológicas de vários diplomatas e funcionários, alguns notórios, como Antônio Houaiss e João Cabral de Melo Neto. Nessa linha de ação, vários postos no exterior foram também colocados a acompanhar as atividades de brasileiros exilados e de estudantes e a permanecer sempre alerta para as notícias consideradas injuriosas contra o regime. Naturalmente, essas funções eram desempenhadas com mais vigor nos países socialistas, onde a crítica ao regime brasileiro se fazia mais destemperadamente e a ação dos brasileiros exilados ou dos estudantes era mais intensa. É digno de nota o fato de que, na documentação enviada à Chancelaria por alguns postos (veja-se, por exemplo, Praga - antiga Checoslováquia), estes eram justamente os assuntos mais freqüentes. Assumindo, pois, a função de monitoramento do comunismo internacional, o Itamaraty pôde constituir um rico acervo sobre o tema, ${ }^{12}$ que diz respeito tanto ao plano interno quanto ao externo. Evidentemente, a documentação do MRE sobre comunismo é muito mais rica no plano externo, haja vista que a função primordial do Itamaraty diz respeito ao relacionamento do Brasil com o 
exterior. Enfim, o acervo do Arquivo Histórico do Itamaraty sobre o tema é provavelmente o mais rico do Brasil e permanece praticamente inexplorado pelos pesquisadores.

Retroagindo aos últimos trinta anos, foi sob a égide do regime militar que se instituiu o Decreto ${ }^{\circ}$ 64.122, de 19-02-1969, que estabelecia as regras de acesso aos documentos do Arquivo, que vigorou até a Constituição de 1988. Segundo este decreto, estabelecia-se a seguinte regra para acesso aos documentos: a) livre acesso aos documentos anteriores a 1900; b) acesso qualificado aos documentos do período 1900-1940; c) acesso proibido aos documentos posteriores a 1940 (note-se que valia a regra dos trinta anos).

As regras supracitadas são lacunares e permitiam uma grande margem de subjetividade. Por exemplo, no item b, "acesso qualificado" quer dizer que o acesso à documentação estava sujeito a autorização administrativa, circunstância que variava de acordo com o funcionário responsável pelo setor e na qual, certamente, havia influência promovida pelas credenciais do pesquisador. Outro aspecto que não fica claro é sobre a possibilidade de acesso aos documentos classificados como secretos e confidenciais no período de 1900 a 1940. De acordo com a prática do Arquivo, possivelmente só aos ostensivos haveria chance de consulta por parte da maioria dos pesquisadores externos aos quadros do Itamaraty. Porém, não se exclui a possibilidade de acesso restrito a documentos classificados como confidenciais ou secretos, dependendo, naturalmente, da qualificação do pesquisador e de seus contatos no Itamaraty.

O debate propiciado pela redemocratização do país na segunda metade dos anos oitenta irá reacender a discussão em torno da problemática do acesso à documentação pública de caráter sigiloso. Na esteira das discussões sobre cidadania, direito à informação e liberdade de expressão, veio à tona a questão sobre os arquivos públicos e o tipo de documentação guardada por eles. Em primeiro lugar, discutiu-se muito sobre os dossiês pessoais elaborados pelos órgãos da repressão e de como desclassificar esta documentação, eliminando assim os resquícios autoritários da época da ditadura militar. Em segundo lugar, e como conseqüência direta da discussão sobre o autoritarismo, buscou-se tratar a questão em um plano maior, discutindo uma nova política nacional de arquivos. Incluiu-se na discussão até mesmo a possibilidade de agrupar todos os documentos produzidos pelos órgãos públicos federais no Arquivo Nacional, questão imediatamente rechaçada pelo Itamaraty, que argumentava a característica peculiar dos documentos da Chancelaria ao mesmo tempo em que fazia comparações com a prática de manterse arquivos diplomáticos junto aos respectivos Ministérios adotada por outros países. Além disso, era preciso adequar as estruturas existentes aos preceitos da Constituição de 1988, que, dentre outros, assevera: "É assegurado a todos o acesso à informação e resguardado o sigilo da fonte, quando necessário ao exercício 
profissional" e "Todos têm direito a receber dos órgãos públicos informações de seu interesse particular, ou de interesse coletivo ou geral, que serão prestadas no prazo da Lei, sob pena de responsabilidade, ressalvadas aquelas cujo sigilo seja imprescindível à segurança da sociedade e do Estado."13

No decorrer do ano de 1988, principalmente durante o segundo semestre, internamente o Itamaraty já estava discutindo a questão e buscando adequar à nova Constituição as normas vigentes de acesso ao seu Arquivo Histórico. O primeiro passo veio com as Portarias $n^{\circ} 593$ e 594, de 12 de outubro de 1988, assinadas pelo Ministro Roberto de Abreu Sodré. A primeira estabelecia o Regulamento da Seção de Arquivo Histórico do Ministério das Relações Exteriores; a segunda criava a Comissão Permanente de Revisão do Arquivo Histórico. ${ }^{14}$

A Portaria $n^{\circ} 593$ regulamentou o acesso aos documentos do Arquivo Histórico. Definiu-se que, a partir daí, o acesso à documentação seria feito após análise e ulterior liberação das solicitações por parte da Comissão Permanente de Revisão do Arquivo Histórico - que sequer havia ainda sido constituída - e deveria ter o endosso por parte do Secretário Geral do Ministério. Estabelecia também que seriam os seguintes os documentos liberados para consulta: a) os que contassem com mais de 30 anos, a contar da data de sua produção e b) os que, embora produzidos há menos de 30 anos, estivessem liberados pela Comissão Permanente de Revisão do Arquivo Histórico. Havia, no entanto, ressalva com relação a duas categorias de documentos que não seriam liberados para consultas: a) os que contivessem informações suscetíveis de pôr em risco a segurança do país e as relações do Brasil com terceiros países ou organismos internacionais e b) os que pudessem afetar a vida privada das pessoas, antes de decorridos 100 anos a contar da data de seu nascimento. ${ }^{15}$ Por fim, a Portaria também disciplinava o uso do Arquivo e concretizava regras para os consulentes, tais como a obrigação de se remeter para a Seção de Arquivo Histórico do Itamaraty uma cópia de eventual trabalho publicado (que tivesse sido resultado das pesquisas feitas na documentação do Arquivo) e a possibilidade de fotocópias dos documentos, uma vez custeadas pelo interessado.

O objetivo do Itamaraty com a criação da Comissão Permanente de Revisão do Arquivo Histórico era o de conduzir prévia revisão da documentação histórica do Ministério visando à liberação dos documentos. Na verdade, a idéia partia da premissa de que interessava ao Itamaraty uma abertura gradual e sistemática do seu acervo, como salientava o presidente da Comissão Permanente, Embaixador Sérgio F. Guarischi Bath. ${ }^{16}$ A Comissão, que seria formada por 4 diplomatas e 2 historiadores (ou profissionais ligados à área de relações internacionais ou documentação) teria por função "proceder à revisão e reclassificação sistemática da documentação sob a guarda da Seção de Arquivo Histórico do Ministério das Relações Exteriores". Dentre suas funções, a Comissão deveria “recomendar a 
eventual reclassificação de documentos, a liberação de consultas aos documentos, o descarte de documentos desprovidos de interesse histórico ou prático e a restauração de documentos de relevante valor histórico". ${ }^{17}$

O ponto de vista do Itamaraty sobre a questão relacionava-se principalmente com a natureza dos documentos de seu acervo. Segundo interpretações de dentro do Ministério, há no Arquivo muitos documentos sensíveis e que poderiam afetar ou comprometer a ação do Estado no plano internacional. Estes temas, freqüentemente abordados na documentação diplomática, estariam ligados a assuntos tais como: defesa nacional, segurança e relações internacionais, pareceres internos, tomadas de decisão, informações confidenciais prestadas por terceiros, informações sobre atividades econômicas e comerciais que porventura pudessem estar em andamento e que, se divulgadas, poderiam prejudicar a posição negociadora do país e temas que de alguma maneira pudessem estar relacionados com a aplicação da lei (prevenção, detecção e julgamento de atividades ilegais), o que certamente causaria, no mínimo, embaraços para o país. Mas havia três temas que realmente incomodavam o Itamaraty e que foram motivos de proposta de constarem em uma lista de exceções: 1) aqueles que pudessem afetar a segurança e as relações internacionais do Brasil, 2) os relativos a questões de fronteiras, 3) os que, porventura, pudessem caracterizar a interferência em assuntos internos de outros países ou de organismos internacionais.

A decisão do Itamaraty de estabelecer reservas para acesso aos documentos e estipular como uma das tarefas da Comissão Permanente justamente este ponto causou certo mal-estar no meio acadêmico interessado no assunto e em setores da imprensa nacional, que se indignaram perante o fato de que, mesmo com a abertura à vista, haveria ainda documentos proibidos ao público. Entre janeiro e fevereiro de 1989, artigos publicados em jornais nacionais estampavam títulos tais como: "Itamaraty torna difícil acesso a seu arquivo"(O Estado de São Paulo, 19/01/1989), "Informações: direito que a Constituição garante e o Itamaraty nega" (Jornal da Tarde, 23/01/1989), "Itamarati ${ }^{18}$ facilitará o acesso a arquivo, mas esconderá documentos" (Jornal do Brasil, 28/01/89), "A Traição Inconstitucional" (Tribuna da Imprensa, 01/02/1989),"Professores são contra a proibição" (Folha de São Paulo, 02/02/1989), "Decisão do Itamaraty restringe o acesso de pesquisadores a arquivo" (Folha de São Paulo, 02/02/1989), "A Lei de Taylor" (Jornal do Brasil, 05/02/1989 - artigo do cientista social Paulo Sérgio Pinheiro sobre a pesquisa no arquivo do Itamaraty e sobre a Comissão Permanente), "Equívocos e Compreensão" (Jornal do Brasil, 05/02/1989 - artigo assinado pelo historiador José Murilo de Carvalho sobre as incompreensões com relação à Comissão Permanente, da qual era membro), "EUA: poucos impedimentos" (Jornal do Brasil, 05/02/1989), "Tutela da História” (Folha de São Paulo, 07/02/1989) e "Itamarati ${ }^{19}$ mantém seus arquivos fechados" (Tribuna da Imprensa, 13/02/1989). 
Nestes artigos, a crítica recaía principalmente sobre o fato de o Itamaraty desejar manter controle sobre o acervo do Arquivo Histórico, liberando alguns documentos e mantendo em sigilo outros. Criticou-se muito, também, a composição da Comissão Permanente a qual, por conter maior número de diplomatas, portanto membros da corporação, tenderia a ser mais discricionária e poderia manter em sigilo assuntos que, na opinião dos críticos, deveriam ser liberados. Porém, o ponto mais polêmico, talvez por falta de informações mais precisas por parte da Comissão, relacionava-se com o desejo do Itamaraty de manter sob sigilo documentos que pudessem prejudicar a imagem de personalidades. Assim, até aquele momento, havia a decisão de que os documentos que pudessem afetar a imagem das pessoas ficariam guardados por um período de cem anos, ou mais. As opiniões contrárias, emanadas por parte dos pesquisadores e encampadas pela imprensa, variavam pouco. Hélio Silva havia considerado a idéia "totalmente absurda". ${ }^{20}$ Para Maria Luiza Tucci Carneiro, que, anos antes, havia entrado em franca polêmica com a família de Oswaldo Aranha em decorrência de um trabalho publicado sobre o antisemitismo no Brasil, tal decisão iria "encobrir interesses de famílias e personalidades diplomáticas reconhecidas internacionalmente e que não fazem questão de assumir diante da história responsabilidades que lhes seriam atribuídas, na medida em que esses documentos viessem à luz"; já para Maria Victória Benevides, esta idéia de impedir o acesso a documentos que prejudiquem a imagem de pessoas nascidas há menos de cem anos parte de uma "visão autoritária e burocrática, pois em país algum do mundo ocidental civilizado existe uma coisa desta. Acho que 25 ou 30 anos já é muito". Por sua vez, Emília Viotti da Costa, indagada sobre a decisão do Itamaraty, considerou-a "um absurdo e que parte de uma concepção equivocada da relação entre o Estado e a Sociedade”. Por fim, para Paulo Sérgio Pinheiro, a "proposta é insustentável e não deve prevalecer", e ao compará-la com os Estados Unidos completava que lá "liberam seus documentos em 30 anos e (n)a França em 50 , às vezes menos". ${ }^{21}$

A Comissão foi finalmente instituída e, em 9 de março de 1989, iniciou seus trabalhos, sendo composta, como dito, por quatro diplomatas (Sérgio F. G. Bath, Lauro Escorel de Moraes, Donatello Grieco e Heitor Pinto de Moura) e dois professores (José Murilo de Carvalho e Marcelo Paiva de Abreu). Os problemas encontrados pela Comissão certamente foram enormes. As pressões e críticas, que começaram antes mesmo do início dos seus trabalhos, também. Desta forma, comprometeu-se o desempenho da Comissão que, sabidamente, tinha um longo e árduo caminho a percorrer, tal a magnitude das atribuições e tarefas a desempenhar (a leitura e desclassificação de quilômetros de documentos, prováveis divergências internas - dada a natureza do trabalho - escassez de pessoal qualificado e de recursos, pareceres sobre solicitações de pesquisa, dentre outros). Enfim, tendo iniciado formalmente seus trabalhos em março de 1989, a Comissão Permanente 
teve vida curta, tendo sido extinta em 1992, deixando, portanto, o trabalho inconcluso. Voltava-se, assim, ao estágio anterior no que diz respeito à forma de acesso à documentação, ${ }^{22}$ que afinal de contas ainda não fora desclassificada de acordo com a legislação vigente.

Como conseqüência da publicação da Lei ${ }^{\circ}$ 8.159, o Ministro das Relações Exteriores, Celso Lafer, fez publicar a Portaria de 27 de agosto de 1992 que revogou as disposições contidas nas Portarias 593 e 594, extinguiu a Comissão Permanente de Revisão do Arquivo Histórico - transferindo suas funções para a Comissão de Estudos de História Diplomática - e aprovou o novo regulamento da Seção de Arquivo Histórico, que basicamente não sofreu alterações substanciais com relação ao regulamento anterior (contido na Portaria $n^{\circ} 593$ ).

Após a extinção da Comissão Permanente, o Itamaraty criou a Comissão de Estudos de História Diplomática, que tem entre suas principais funções as seguintes: a) analisar as solicitações de pesquisa à luz da legislação em vigor, b) desclassificar documentos que considere não mais sigilosos, uma vez contemplados pela legislação, c) propor publicação e divulgação de documentos de interesse histórico-diplomático, estudos, catálogos ou bibliografia de história diplomática, d) promover a realização de cursos e conferências sobre temas de história diplomática ou relevante interesse, e) propor a atualização das normas de acesso à documentação de história diplomática existentes no Arquivo Histórico do Rio de Janeiro e proceder à revisão dos documentos que se encontram no Arquivo do Ministério das Relações Exteriores, f) dar pareceres sobre pedidos de consulta formulados por pesquisadores brasileiros e estrangeiros, desde que solicitado pela Divisão de Comunicações e Arquivo, e g) recomendar a restauração de documentos de relevante valor histórico. $^{23}$

Sediada no Rio de Janeiro desde a data de sua criação - 30 de setembro de 1992 -, a Comissão de Estudos de História Diplomática (CEHD) é composta por 7 membros. De acordo com o artigo $4^{\circ}$ da Portaria de criação da mesma (30/ 7/1992), a sua composição dever-se-ia fazer com quatro membros extraídos dos quadros do Itamaraty e três escolhidos entre "brasileiros de notável saber histórico, em consulta com entidades da comunidade acadêmica". ${ }^{24}$ Muito embora seja louvável a iniciativa do Itamaraty de estabelecer esta Comissão, o que se constata é que, dentre todas as atribuições que lhe foram outorgadas, a que mais vem sendo desempenhada é a que diz respeito à análise das solicitações de pesquisa, sobre as quais são emitidos pareceres a pedido da Divisão de Comunicação e Arquivo.

Em 1991, o Congresso Nacional aprovou nova lei visando ao estabelecimento e à normatização de uma política nacional de arquivos. ${ }^{25}$ A questão do acesso aos arquivos, incluindo o acesso aos documentos sigilosos, foi contemplada na lei, o que obrigou a revisão dos procedimentos de pesquisa no arquivo do Itamaraty. O capítulo V ("Do Acesso e do Sigilo dos Documentos Públicos") 
assegura o direito de acesso pleno aos documentos públicos (artigo 22), mas ressalva, no artigo $23 \S 2^{\circ}$ e $3^{\circ}$, que "o acesso aos documentos sigilosos referentes à segurança da sociedade e do Estado será restrito por um prazo máximo de 30 anos, a contar da data de sua produção, podendo esse prazo ser prorrogado, por uma única vez, por igual período" e que "o acesso aos documentos sigilosos referentes à honra e à imagem das pessoas será restrito por um prazo de 100 anos, a contar da data de sua produção". Com relação às categorias de sigilo que deveriam reger a classificação dos documentos, estas seriam estabelecidas posteriormente, através de Decreto.

A novidade mais importante introduzida pela Lei $N^{\circ} 8.159$ - e no que diz respeito ao acervo documental do Itamaraty, regulamentada pela Portaria de $27 \mathrm{de}$ agosto de 1992 - foi a possibilidade de prorrogar por igual período (30 anos) a restrição à consulta de documentos sigilosos referentes à segurança do Estado e da sociedade. Desta maneira, nos termos da lei, haveria possibilidade de manterse o impedimento à consulta de certos documentos por um período de até 60 anos, sem contar, naturalmente, que os documentos referentes à imagem das pessoas seriam mantidos em sigilo por até 100 anos, período este contado a partir da data de nascimento da pessoa. Noutro sentido, a possibilidade de liberação de documentos classificados como sigilosos, que tivessem menos de 30 anos, poderia ocorrer, desde que aprovada sua liberação pela Comissão de Estudos de História Diplomática. ${ }^{26}$

Finalmente, em janeiro de 1997, o Decreto ${ }^{\circ} 2.134$, de 24/01/1997, regulamentou o artigo 23 da lei $n^{\circ} 8.159$, de 08/01/1991. Completou-se, assim, a legislação vigente sobre classificação, reprodução e acesso aos documentos públicos sigilosos. Sobre o acesso à documentação, o referido Decreto estipula que qualquer documento de natureza sigilosa que já tenha sido objeto de consulta pública não poderá sofrer restrição de acesso e que "serão liberados à consulta pública os documentos que contenham informações pessoais desde que previamente autorizada pelo titular ou por seus herdeiros". ${ }^{27}$ Caso o órgão responsável pela guarda dos documentos denegue pedido de acesso a algum pesquisador, faz-se necessário justificar por escrito, explicando os motivos da negativa. ${ }^{28}$

No tocante ao grau de sigilo atribuído aos documentos e aos prazos de restrição ao acesso, ficou estabelecido que estes se dividem em quatro níveis, a saber:

1) Ultra-Secretos, máximo de trinta anos;

2) Secretos, máximo de vinte anos;

3) Confidenciais, máximo de dez anos;

4) Reservados, máximo de cinco anos. ${ }^{29}$

Contudo, o Decreto mantém a possibilidade de se prorrogar, por igual período, e uma única vez, a restrição à consulta de documentos sigilosos, desde que 
considerado "o interesse da segurança da sociedade e do Estado". Da mesma forma, acabou prevalecendo a restrição de acesso aos documentos que, porventura, possam comprometer "a intimidade, a vida privada, a honra e a imagem das pessoas" (acrescentando-se documentos que integram processos judiciais tramitados em segredo de justiça), os quais só serão liberados em um prazo de cem anos contados a partir da data de sua produção. ${ }^{30}$

\section{A pesquisa no arquivo do Itamaraty}

No âmbito deste artigo, procedemos à análise das pesquisas solicitadas aos arquivos do Itamaraty, no Rio de Janeiro e em Brasília. Para tanto, foram considerados os "formulários de pesquisa" disponibilizados para consulta para este artigo junto à Seção do Arquivo Histórico em Brasília, bem como os memorandos que tratam do assunto e a legislação pertinente. ${ }^{31}$

Muito embora estejamos conscientes de que, possivelmente, nem todo o universo das pesquisas solicitadas pôde ser contemplado neste trabalho, consideramos o número de formulários abarcados satisfatório para uma análise bem próxima da realidade, refletindo tendências no campo das pesquisas efetuadas no arquivo do Itamaraty.

Foram analisados 184 pedidos de pesquisa, sendo que alguns deles feitos por grupos de pesquisadores. Nossa pesquisa contemplou tanto as solicitações feitas em Brasília, quanto aquelas feitas ao Arquivo Histórico no Rio de Janeiro, e das quais foram enviadas cópias para arquivamento em Brasília. No que diz respeito às pesquisas solicitadas à Seção do Arquivo Histórico em Brasília, foi possível localizar número bem aproximado do total de pesquisas solicitadas, dado que a Seção arquivou os pedidos de pesquisa em pastas apropriadas. Com relação ao Rio de Janeiro é que restam dúvidas acerca do número real de pesquisas solicitadas e do número de cópias dos formulários encontrados em Brasília. É bem provável que alguns formulários não tenham sido enviados para arquivamento em Brasília. De qualquer maneira, o número de formulários analisados é suficiente para uma amostragem que é indicativa do tipo de interesse despertado nos pesquisadores pelo arquivo do Itamaraty.

Como metodologia de trabalho para a análise desses formulários, extraímos todos os dados possíveis encontrados no "modelo de formulário" adotado pelo Itamaraty, resultando em quadros que visam à sistematização. Coligimos, destarte, a relação de todos os temas de pesquisas solicitadas utilizando, para tanto, o título indicado pelo pesquisador para a sua pesquisa. Além disso, foram elaborados três quadros (ver anexos) contendo informações específicas sobre: a) o perfil profissional dos pesquisadores, b) a origem dos pesquisadores estrangeiros, e c) o estudo das relações bilaterais. 
A análise desses dados mostrou-se extremamente interessante. Para efeito de sistematização, dividimos as pesquisas solicitadas em cinco blocos temáticos que, embora um tanto flexíveis e admitindo subdivisões, permitem dar certa unidade aos pedidos diversos. Em volume de pesquisas solicitadas, eles assim estão divididos: Temas de Política Externa (116), História do Brasil (33), Biografia/Memória (23), Temas Internacionais Contemporâneos (6) e Temas Gerais (6).

O grupo denominado de Temas de Política Externa subdivide-se em outros três, a saber: relações bilaterais do Brasil (58), política externa brasileira (34) e relações multilaterais/organizações internacionais/Cone Sul (24). O tópico relativo às relações bilaterais aparece com folgada vantagem sobre os demais. Como o próprio tema sugere, são estudos voltados para a interpretação das relações entre o Brasil e outros países, em diferentes períodos históricos. As pesquisas solicitadas comumente têm caráter generalizante, compreendendo múltiplos níveis, como econômico, social, político e cultural. No entanto, algumas pesquisas se concentraram em temas específicos, tais como Cooperação Científica e Tecnológica e Cooperação Nuclear do Brasil com um determinado país. No geral, a ênfase recai, contudo, nos aspectos políticos e diplomáticos propriamente ditos das relações exteriores do Brasil. É, também, interessante notar que, no cômputo geral das pesquisas sobre as relações bilaterais, houve preferência dirigida para os seguintes países: Argentina (9), Estados Unidos (6), Alemanha (6), França (4), Inglaterra (4), Portugal (3) e Paraguai (3), sendo que, com os demais países, se percebe maior pulverização. ${ }^{32}$

Quando se analisa a representação por continente no âmbito das relações bilaterais, conclui-se que a Europa aparece em primeiro lugar, com dez países representados. Em seguida aparecem: América do Sul (7), América do Norte, Central e Caribe (4), África (3), Oriente Próximo (1) e Ásia (1). Por um lado, estes resultados evidenciam o grande interesse despertado por Europa, Estados Unidos e América do Sul (especificamente pelo Cone Sul, com ênfase para Argentina, Paraguai e Bolívia. Curiosamente, não aparecem nem o Chile nem o Uruguai) nos pesquisadores que investigam a política externa brasileira, na verdade, constituindo-se em uma tendência já histórica. Por outro, observam-se lacunas importantes na pesquisa, sobretudo no que diz respeito ao continente asiático, que ultimamente vem despertando a atenção da maioria dos analistas das relações internacionais pelo marcante processo de crescimento econômico dos países daquela região verificado nas últimas décadas. Já a África, apesar de ter tido papel de destaque para a diplomacia brasileira nos anos 70 e 80, aparece somente de forma marginal no interesse dos pesquisadores. O quadro das relações bilaterais é, portanto, bastante ilustrativo da ação da diplomacia brasileira, da importância que determinadas áreas possuem para o Brasil e do interesse dos pesquisadores pelos países com 
que o Brasil mantém suas relações, apresentando preferências nítidas com as áreas economicamente mais privilegiadas.

No segundo tópico do primeiro grupo, foram alocados os pedidos de pesquisa referentes a temas mais gerais da política externa brasileira. Neste conjunto, incluem-se estudos tais como a política externa de determinado governo brasileiro (A Política Externa do Governo Dutra, A Política Externa do Governo Kubitschek etc.) e assuntos importantes da agenda externa do país (Amazônia, Política Nuclear, Opinião Pública, Estudo de Direito Internacional Público, a Questão Colonial Portuguesa, Participação do Brasil em Operações de Paz, entre outros). Observação importante a fazer é a lacuna verificada no que diz respeito a temas que utilizam documentação consular, a qual praticamente não despertou interesse entre os pesquisadores. ${ }^{33}$

Ainda no âmbito do primeiro grupo, há um terceiro tópico: o estudo das relações multilaterais/organismos internacionais/Cone Sul. Neste segmento, o destaque fica por conta dos estudos sobre o Cone Sul, que, afinal, ganharam dimensão após a consolidação do Mercosul e a evidência ainda maior da importância da região para o Brasil. Assim, foram solicitadas pesquisas que objetivavam um estudo amplo sobre o Mercosul, das origens do processo de integração regional até o mais atual estágio do bloco, com enfoques que almejavam uma visão em perspectiva ampliada (por exemplo: Relações entre o Mercosul e a Europa Ocidental, Mercosul e Estados Unidos, Relações entre o Mercosul e os outros países da América Latina, Relações do Mercosul com a Europa Oriental e Ásia e Inserção Internacional do Cone Sul). No que diz respeito aos organismos internacionais e às instituições multilaterais, evidencia-se o interesse em se estudar diversos desses organismos tais como: a Liga das Nações (o mais solicitado), o Gatt, a Unctad, a Unesco, o Sistema Interamericano e alguns aspectos da ONU. Com relação a este último, ressalte-se o caráter pontual dos estudos solicitados. Embora muitos pesquisadores contemplem o estudo da atuação do Brasil na ONU como uma parte do seu trabalho, uma única pesquisa foi solicitada para específica investigação do Brasil na ONU, e, mesmo assim, como ressaltado, em caráter pontual (Aspectos das Relações entre o Brasil e a ONU - questão do interesse brasileiro em ser membro do Conselho de Segurança).

O segundo grupo constituído está dedicado ao tema da história do Brasil. Com 33 solicitações de pesquisas efetuadas, o estudo da história do Brasil no arquivo do Itamaraty apresenta dois dados muito interessantes. Em primeiro lugar, há o fato de que as pesquisas de história solicitadas são consideravelmente diversificadas e sugerem que boa parte dos pesquisadores que se dirigiram ao arquivo do Itamaraty o fizeram com a intenção de utilizar as fontes diplomáticas brasileiras mais como um complemento de suas pesquisas do que como as principais para o entendimento do objeto de estudo. Em segundo lugar, é possível identificar, 
na diversidade de temas abordados, um grupo coeso e representativo de pesquisa que é o dedicado ao estudo da problemática dos movimentos de imigração. Com efeito, países importantes que contribuíram com fluxos de migrantes para o Brasil foram contemplados pelos pesquisadores, como Japão, Espanha, Portugal e Alemanha, além de uma curiosa investigação sobre o caso de marroquinos que teriam vindo para o Brasil e do caso específico de um estudo sobre a imigração judaica. É meritoso de nota a ausência de estudo dirigido especificamente para o caso da imigração italiana (pelo menos durante o período demarcado neste artigo), um dos países que mais contribuiu com imigrantes para o Brasil. Neste mesmo sentido, existem lacunas ainda não preenchidas no estudo dos movimentos migratórios mais recentes para o Brasil, tais como os de países do Oriente Próximo, como a Síria e o Líbano, e do Oriente, como a Coréia. E há, ainda, para citarmos somente mais dois vazios nas pesquisas sobre o tema, o caso da migração de latino-americanos para o Brasil (muitos procedentes da Bolívia e do Paraguai, por exemplo) e de refugiados de Angola e outras partes da África que se dirigiram para o Brasil em decorrência da instabilidade política e dos conflitos bélicos no continente africano.

$\mathrm{O}$ terceiro assunto mais solicitado demonstra um aspecto importante do Itamaraty como instituição e do seu arquivo para a história do Brasil, haja vista a passagem pelo Ministério de pessoas de destacada participação na vida política do país. Trata-se da pesquisa que objetiva a elaboração de obras biográficas e de memórias. Personalidades que participaram ativamente da história do Brasil em diversas áreas de atuação - escritores, poetas, presidentes, jornalistas, diplomatas, políticos - aparecem com destaque neste tipo de trabalho, tais como: Euclides da Cunha, Washington Luís, Villa Lobos, o Barão do Rio Branco, Oswaldo Aranha, Assis Chateaubriand, Graça Aranha, Domício da Gama, Princesa Isabel, Clarice Lispector, Tarsila do Amaral, Apolônio de Carvalho e Tancredo Neves.

Como visto, havia excessiva preocupação do Itamaraty em preservar a imagem das pessoas, evidentemente amparado em preceito constitucional. Resulta daí a dificuldade que tiveram os pesquisadores que se dedicaram a estes temas para conseguir a liberação dos documentos necessários ao seu trabalho. Houve casos, por exemplo, em que pessoas que intencionavam resgatar a memória de familiares tiveram pedidos negados.

Mas, não só a preocupação com a memória das pessoas corroborava para o indeferimento de determinada solicitação de pesquisa. A própria disposição dos documentos, colecionados em livros encadernados, dificulta o acesso a vários tipos de pesquisa, sobretudo as que propõem um período temporal mais amplo de investigação. O problema está em que estes livros contêm documentos de vários tipos, misturando assuntos que podem ser considerados de sigilo maior com os que podem eventualmente estar liberados para consulta. Como é praticamente 
impossível impedir que um pesquisador leia outros documentos contidos no mesmo volume, chega-se ao impasse. E a solução adotada costumava ser a de impedir a consulta aos livros ou maços.

Em quarto e quinto lugares, destacam-se os estudos de temas internacionais contemporâneos e de temas gerais. No primeiro grupo, houve a solicitação de seis pesquisas que enfocam assuntos relacionados à história contemporânea, todos do século XX. São temas de interesse geral ou envolvendo diretamente assuntos que dizem respeito a outros países, mas que se desvinculam de um envolvimento específico com a agenda externa brasileira, pelo menos do ponto de vista oficial. São eles: A Guerra Civil Espanhola na Imprensa brasileira, A Revolução Cubana - duas pesquisas - Trabalho Integração e Conflito entre Grupos Étnicos no Nordeste Argentino, A Guerra do Vietnã (especificamente a Ofensiva do Tet, de fevereiro a agosto de 1968) e o Conflito Árabe-Israelense. O reduzido número de pesquisas solicitadas com referência a assuntos ligados à história contemporânea aponta para uma tendência verificada também junto à produção historiográfica como um todo no país. ${ }^{34}$ Finalmente, com relação ao último tópico, denominado "temas gerais", trata-se de seis pesquisas de temas muito diversos e pontuais e que não puderam ser classificados nos agrupamentos anteriores. São eles: A Evolução Gastrológica das Festas Governamentais oferecidas a personalidades estrangeiras pelo Itamaraty, A Fundação de Santo Domingo de Soriano no terceiro quarto do século XVII (Uruguai), A Mulher Paraguaia na Segunda metade do século XIX, o Território de Fernando de Noronha, o Monumento aos iniciadores americanos da aviação e uma solicitação de Informações sobre o desenhista e o ourives que idealizaram os colares de água-marinha e brilhantes doados pelo governo brasileiro à Rainha Elizabeth II, da Grã-Bretanha, por ocasião de sua coroação, formulado pelo Arquivo Real dos Países Baixos.

O perfil profissional dos pesquisadores que utilizaram o arquivo do Itamaraty demonstra-nos uma variada gama de origens profissionais. Constam desta lista as seguintes profissões, em ordem de solicitações: Professores (98), Estudantes (31), Diplomatas (16), Jornalistas (10), Advogados (8), Economistas (5), Engenheiros (2), Militares (2), Oficial de Chancelaria (1), Tradutor (1), Clérigo (1), Médico (1), Bibliotecário (1), Arquivista (1), Estagiário (1) e Indeterminados (5). Estes dados indicam que as Universidades (incluindo os cursos de pós-graduação, haja vista que a maioria dos estudantes que solicitou pesquisas o fez tendo em mente a elaboração de dissertações de mestrado e teses de doutorado) se constituem no público mais interessado na utilização das fontes disponíveis no Itamaraty. Muito embora haja uma freqüência anual média que se mantém no período selecionado para a pesquisa, no que diz respeito às solicitações de pesquisa por parte dos profissionais oriundos da academia, há uma tendência para o crescimento deste 
tipo de usuário, sobretudo porque o estudo da política externa brasileira e das relações internacionais vem crescendo consideravelmente no país nos últimos anos, com o surgimento de vários novos cursos de graduação em Relações Internacionais e da consolidação da pós-graduação na área (em História, Relações Internacionais e áreas afins), que é o caso, por exemplo, da Universidade de Brasília. Em segundo lugar, os dados demonstram o caráter funcional do Arquivo para os diplomatas, que freqüentemente recorrem aos documentos, seja para a elaboração de suas teses de promoção profissional, seja para a utilização de documentos do Arquivo como fontes para esclarecer questões recorrentes de política externa brasileira, que são usadas em seus relatórios, estudos e memorandos.

Um dado importante revelado na pesquisa diz respeito aos pesquisadores estrangeiros que requereram autorização para efetuar consultas no arquivo do Itamaraty. Em primeiro lugar, chame atenção pelo fato de representarem cerca de $30 \%$ dos pedidos solicitados. É um número relativamente alto. Em segundo lugar, pelo fato de procederem de 25 diferentes países, representando, pois, todos os continentes.

Os argentinos e os norte-americanos foram os que mais solicitaram acesso ao arquivo do Itamaraty. Foram nove solicitações feitas por dois grupos de pesquisadores argentinos; a primeira em 1994 e a segunda em 1995. Já os norteamericanos aparecem igualmente com nove solicitações, porém, de forma individual.

No que tange aos argentinos, a permissão para a pesquisa com relação à solicitação do primeiro grupo foi postergada pelo Itamaraty em decorrência da abordagem generalizante e pela falta de adequação da solicitação à legislação vigente, o que levou à desistência da pesquisa por parte dos pesquisadores. $\mathrm{O}$ segundo grupo teve seu pedido atendido, mas, por tratar-se de um projeto conjunto com professores brasileiros, a freqüência dos argentinos resultou muito restrita. E é ponto para reflexão o fato de que justamente a segunda solicitação, com participação de notórios professores brasileiros, é que tenha sido a atendida, sobretudo porque ambas propunham o estudo de temas afins: a primeira, o Mercosul; a segunda, a inserção internacional do Cone Sul, em uma perspectiva cronológica muito mais ampla. Enfim, no caso dos pesquisadores argentinos, é preciso relativizar os valores absolutos da pesquisa com os dados reais de acesso à documentação. Neste caso específico, foi possível acompanhar toda a tramitação do pedido e observar o resultado final, acima destacado.

Juntamente com os argentinos, os norte-americanos aparecem no topo da lista com nove pedidos de pesquisa solicitados ao Itamaraty. Contudo, diferentemente dos primeiros, os pesquisadores provenientes dos Estados Unidos caracterizam-se por uma diversidade maior com relação aos temas de pesquisa. Das nove solicitações, três visam ao estudo de história das relações internacionais: duas sobre as relações Brasil-Estados Unidos e uma sobre Brasil e África (esta última 
não foi efetivamente levada a efeito). Os outros temas, à exceção de uma biografia de Oswaldo Aranha, buscam o estudo da História do Brasil, em vários aspectos: História da imigração no Brasil (1950-1959); história do clero brasileiro e do clero estrangeiro no Brasil (1930-1980); Família, alimentação e trabalho nos empreendimentos de extração de borracha da Ford no Brasil (1929-1945); Da escravidão à liberdade na Bahia (1791-1900); O culto da santidade no século XVI no Brasil.

De outras nacionalidades, destaque para três solicitações de pesquisa por parte de pesquisadores dos seguintes países: Alemanha, França, Portugal e Uruguai. Os demais países, relacionados em anexo, tiveram um único pesquisador solicitando acesso ao Arquivo. Destes, a maioria solicitou pesquisas relacionadas ao tema das relações bilaterais ou algum aspecto da política externa brasileira.

Dos ausentes, destaque maior pode ser dado, na América, aos bolivianos e paraguaios; e, na Europa, aos italianos e espanhóis. Bolívia e Paraguai são países limítrofes e para os quais o Brasil representa muito em termos estratégicos e econômicos e, quando se considera a importância política que este tem para aqueles, influencia de certa maneira na vida política daquelas nações, evidenciando-se uma extensa lacuna para as ciências sociais e a história das relações internacionais de ambos. Afinal, muitos mitos e interpretações genuinamente nacionais poderiam ser revistos. Itália e Espanha, mais o primeiro que o segundo, também possuem um histórico de relacionamento com o Brasil muito importante, realçado pela presença de imigrantes, investimentos e por momentos históricos marcantes. A compreensão mútua só teria a ganhar com a presença de pesquisadores destes países no arquivo diplomático brasileiro.

Outra característica encontrada nas solicitações de pesquisa por parte dos estrangeiros diz respeito aos objetivos das pesquisas solicitadas. Com efeito, $40 \%$ dos objetivos declarados indicavam a preparação de teses de doutorado, $29 \%$ a confecção de livros, $22 \%$ indeterminados, $7 \%$ dissertações de mestrado e $2 \%$ a elaboração de artigo. É possível conjeturar sobre a qualificação do pesquisadores estrangeiros, que aparentemente detêm boa qualificação e experiência no campo da pesquisa (alguns, naturalmente, são cientistas sociais e historiadores bastante conhecidos no Brasil, como Stanley Hilton, por exemplo).

Ao se confrontar a sistemática de análise para permissão de acesso aos documentos contidos no arquivo do Itamaraty por parte dos pesquisadores nacionais com as solicitações elaboradas por estrangeiros, percebe-se maior preocupação e rigor com a análise das propostas de pesquisa. Isto se explica pelo fato de o Arquivo conter documentação diplomática afeta ao relacionamento do Brasil com outros países, emanando daí, inevitavelmente, uma série de impressões e pontos de vista oficiais do Brasil com relação a outros países, o que poderia, dependendo da utilização da informação, causar certos embaraços para a diplomacia brasileira. 
Assim, houve casos de negação de pedidos por parte do Itamaraty, seja pela delicadeza das matérias propostas, como por exemplo, no caso das disputas entre Equador e Peru por uma região fronteiriça que levou recentemente a conflitos armados entre os dois países, seja pela simples constatação de que, para o pedido proposto, o acervo do Arquivo não conteria documentação adequada. Há, ainda, a não realização de pesquisas simplesmente porque o pesquisador solicitou o acesso ao Arquivo, teve seu pedido atendido, porém nunca apareceu para realizar a pesquisa. Ressalte-se, entretanto, que a política de restrição e/ou acesso à documentação também prevalece para pesquisadores brasileiros, existindo vários casos de denegação de pedidos.

\section{Conclusão}

$\mathrm{O}$ acesso ao Arquivo Histórico do Itamaraty sempre foi visto pelos historiadores, e pelos interessados em estudar as relações internacionais do Brasil, como muito problemático. Sem dúvida, esta não era uma percepção equivocada. As dificuldades que quase impediam totalmente a investigação no arquivo diplomático brasileiro foram gradualmente sendo removidas. O interesse sobre a política internacional, cada vez mais manifestado pela sociedade, vem contribuindo de maneira decisiva para a abertura da documentação diplomática brasileira e abrindo espaços para uma mudança qualitativa das discussões em torno do tema.

Corroborando com esta assertiva, o meio acadêmico brasileiro conta atualmente com dois cursos de pós-graduação voltados especificamente para o estudo da História das Relações Internacionais: um na Universidade de Brasília (UnB), funcionando desde meados da década de 1970 e que possui dois níveis de pós-graduação - Mestrado e Doutorado -, já tendo produzido substancial conhecimento nessa área; e outro, mais recente, constituído na Universidade Estadual do Rio de Janeiro (UERJ) com o nível de Mestrado. Some-se a isso o fato de existirem no país outros cursos de pós-graduação na área de Relações Internacionais - na Universidade de Brasília e na Pontifícia Universidade Católica do Rio de Janeiro (PUC), ambos com o nível de Mestrado.

As mudanças introduzidas com a redemocratização do país e com Constituição de 1988 abriram novas perspectivas para a pesquisa histórica no arquivo do Itamaraty. Após 1988 e até a regulamentação da legislação de acesso à documentação em 1997, lentamente operou-se produtiva transformação na mentalidade e na política de acesso a documentos públicos no país. Desta forma, o público interessado na história da política exterior do Brasil, e no estudo das relações internacionais, tem agora à disposição um rico e valioso acervo documental que servirá como subsídio para a compreensão e explicação da inserção internacional 
do país, suas relações com outras nações e a consolidação do conhecimento nacional sobre um tema que vem ganhando destaque nos últimos anos.

Ainda não explorado de forma consistente pelos pesquisadores, talvez por falta de conhecimento das transformações que operaram a liberação do seu acervo, o arquivo do Itamaraty, com a valiosa documentação disponível, certamente se constitui em fonte inesgotável - e praticamente virgem - de fontes para a História do Brasil. A liberação do acervo vem, portanto, em momento profícuo em que a academia se esforça para consolidar a área dos estudos de política internacional, estreitando o intercâmbio entre as universidades e o Ministério das Relações Exteriores.

Sem embargo, a possibilidade de acesso à documentação, assegurada por legislação das mais liberais, além de promover a produção de conhecimento histórico de qualidade e embasado em fontes primárias, irá permitir uma revisão do conhecimento acerca da história das relações internacionais do Brasil e consolidar maior participação da sociedade nos rumos da política externa brasileira. Portanto, contando com uma produção sólida referente ao tema em apreço, e que dispõe de valiosas contribuições que já se tornaram clássicas - como os estudos dos professores Amado L. Cervo, Clodoaldo Bueno, Gerson Moura, José Flávio S. Saraiva, José Honório Rodrigues e Moniz Bandeira ${ }^{35}$ (entre outros) -, os pesquisadores preocupados em aprofundar e fazer avançar o conhecimento e a reflexão sobre os assuntos voltados para a inserção internacional do Brasil certamente serão beneficiados pela possibilidade de acesso a fontes imprescindíveis para a compreensão dessa vertente da História do Brasil, para a qual o acervo do Arquivo Histórico do Itamaraty é fundamental, e sem o qual prevaleceria tão somente o conhecimento produzido através de fontes estrangeiras, o que resultaria em uma visão parcial e em perspectiva que não corresponderia a uma visão brasileira sobre temas tão relevantes para o país. 


\begin{abstract}
Anexos
Quadro 1

Estudo das Relações Bilaterais (1987-1998)

ESTUDOS DE RELAÇÕES BILATERAIS
\end{abstract}

\begin{tabular}{|c|c|c|c|c|c|c|c|c|c|c|c|c|c|}
\hline \multirow{2}{*}{ RELAÇÕES BRASIL } & \multicolumn{13}{|c|}{ ANOS } \\
\hline & 87 & 88 & 89 & 90 & 91 & 92 & 93 & 94 & 95 & 96 & 97 & 98 & Total \\
\hline África do Sul & - & - & - & - & - & - & - & - & - & - & 1 & - & 1 \\
\hline Alemanha & - & - & - & - & 1 & 1 & - & 2 & - & 1 & 1 & - & 6 \\
\hline Argentina & - & - & 2 & - & 2 & 1 & - & 1 & 1 & - & - & 2 & 9 \\
\hline Austro-Húngaro (Império) & - & - & - & - & - & - & 1 & - & - & - & - & - & 1 \\
\hline Bolívia & 1 & 1 & - & - & - & - & - & - & - & - & - & - & 2 \\
\hline China & - & - & - & - & - & - & - & - & 1 & - & - & - & 1 \\
\hline Colômbia & - & - & - & - & - & - & - & - & 1 & - & - & - & 1 \\
\hline Costa Rica & 1 & - & - & - & - & - & - & - & - & - & - & - & 1 \\
\hline Cuba & - & - & - & - & - & - & 1 & - & - & - & - & - & 1 \\
\hline Equador & - & - & - & - & - & - & - & - & 1 & - & - & 1 & 2 \\
\hline Espanha & - & - & - & - & - & - & - & 1 & - & - & - & - & 1 \\
\hline Estados Unidos & 1 & 2 & - & - & 1 & 1 & - & - & - & - & 1 & - & 6 \\
\hline França & - & - & - & - & - & - & - & - & 2 & 2 & - & - & 4 \\
\hline Inglaterra & - & - & - & 1 & - & - & - & - & - & 1 & - & 2 & 4 \\
\hline Irlanda & - & - & - & - & - & - & - & - & - & - & 1 & - & 1 \\
\hline Israel & - & - & - & - & - & - & - & - & - & - & - & 1 & 1 \\
\hline Itália & - & - & - & - & - & - & 1 & - & - & - & - & - & 1 \\
\hline Marrocos & 1 & - & - & - & - & - & - & - & - & - & - & - & 1 \\
\hline México & - & - & - & - & - & - & - & - & - & - & 1 & - & 1 \\
\hline Paraguai & 1 & - & - & - & - & - & - & 2 & - & - & - & - & 3 \\
\hline Peru & - & - & - & - & - & - & - & - & 1 & - & - & - & 1 \\
\hline Portugal & - & - & - & - & - & 1 & - & 2 & - & - & - & - & 3 \\
\hline Rússia (Império) & - & 1 & - & - & - & - & - & - & - & - & - & - & 1 \\
\hline Senegal & - & - & - & - & - & 1 & - & - & - & - & 1 & - & 2 \\
\hline Vaticano (Santa Sé) & - & - & - & - & - & - & 1 & - & - & - & - & - & 1 \\
\hline Venezuela & - & - & 1 & - & - & - & - & - & - & - & - & - & 1 \\
\hline Subtotal/Total & 5 & 4 & 3 & 1 & 4 & 5 & 4 & 8 & 7 & 4 & 7 & 6 & 58 \\
\hline
\end{tabular}

Fonte: Formulários de solicitação de pesquisa arquivados na Seção de Arquivo Histórico do Itamaraty em Brasília. 


\section{Quadro 2}

Perfil Profissional dos Pesquisadores que Solicitaram Pesquisas no Arquivo do Itamaraty (1987-1998)

\begin{tabular}{|c|c|c|c|c|c|c|c|c|c|c|c|c|c|}
\hline \multicolumn{14}{|c|}{ PERFIL PROFISSIONAL DOS PESQUISADORES } \\
\hline \multirow{2}{*}{ PROFISSÃO } & \multicolumn{13}{|c|}{ ANOS } \\
\hline & 87 & 88 & 89 & 90 & 91 & 92 & 93 & 94 & 95 & 96 & 97 & 98 & Total \\
\hline Professor/Pesquisador & 14 & 9 & 9 & - & 7 & 10 & 3 & 13 & 14 & 3 & 7 & 9 & 98 \\
\hline Estudante & - & 3 & - & 1 & 1 & 1 & - & 4 & 3 & 4 & 8 & 6 & 31 \\
\hline Diplomata & 2 & 1 & - & - & 4 & - & 1 & - & 1 & 2 & 3 & 2 & 16 \\
\hline Jornalista & 2 & 2 & - & 1 & - & - & 2 & - & - & 2 & 1 & - & 10 \\
\hline Advogado & 2 & 1 & - & - & - & - & 2 & 1 & 1 & - & 1 & - & 8 \\
\hline Economista & - & 1 & - & - & - & - & 1 & 1 & 2 & - & - & - & 5 \\
\hline Engenheiro & 1 & 1 & - & - & - & - & - & - & - & - & - & - & 2 \\
\hline Militar & 1 & - & - & - & - & - & 1 & - & - & - & - & - & 2 \\
\hline Oficial de Chancelaria & - & - & - & - & - & - & - & - & - & - & - & 1 & 1 \\
\hline Tradutor & - & 1 & - & - & - & - & - & - & - & - & - & - & 1 \\
\hline Clérigo & - & - & - & - & - & - & - & - & 1 & - & - & - & 1 \\
\hline Médico & - & - & - & 1 & - & - & - & - & - & - & - & - & 1 \\
\hline Bibliotecário & - & - & - & 1 & - & - & - & - & - & - & - & - & 1 \\
\hline Arquivista & 1 & - & - & - & - & - & - & - & - & - & - & - & 1 \\
\hline Estagiário & - & - & - & - & - & - & - & - & - & - & - & - & 1 \\
\hline Indeterminado & - & 3 & 2 & - & - & - & - & - & - & - & 1 & - & 5 \\
\hline Subtotal/Total & 23 & 22 & 11 & 4 & 12 & 11 & 10 & 19 & 22 & 11 & 21 & 18 & 184 \\
\hline
\end{tabular}

Fonte: Formulários de solicitação de pesquisa arquivados na Seção de Arquivo Histórico do Itamaraty em Brasília. 


\section{Quadro 3}

Pesquisadores Estrangeiros que Solicitaram Pesquisa no Arquivo do Itamaraty (1987-1998)

\begin{tabular}{|c|c|c|c|c|c|c|c|c|c|c|c|c|c|}
\hline \multicolumn{14}{|c|}{ PESQUISADORES ESTRANGEIROS } \\
\hline \multirow{2}{*}{ PAÍS DE ORIGEM } & \multicolumn{13}{|c|}{ ANOS } \\
\hline & 87 & 88 & 89 & 90 & 91 & 92 & 93 & 94 & 95 & 96 & 97 & 98 & Total \\
\hline Alemanha & - & - & 1 & - & - & - & - & - & - & - & 1 & 1 & 3 \\
\hline Argentina & - & - & - & - & - & - & - & 5 & 4 & - & - & - & 9 \\
\hline Austrália & 1 & - & - & - & - & - & - & - & - & - & - & - & 1 \\
\hline Áustria & - & 1 & - & - & - & - & - & - & - & - & - & - & 1 \\
\hline Colômbia & - & - & - & - & - & - & - & - & 1 & - & - & - & 1 \\
\hline Costa do Marfim & - & - & - & - & - & - & - & - & 1 & - & - & - & 1 \\
\hline Costa Rica & 1 & - & - & - & - & - & - & - & - & - & - & - & 1 \\
\hline Cuba & - & - & - & - & - & - & 1 & - & - & - & - & - & 1 \\
\hline Equador & - & - & - & - & - & - & - & - & - & - & - & 1 & 1 \\
\hline Estados Unidos & 2 & - & 1 & - & 1 & 3 & - & - & - & 1 & 1 & - & 9 \\
\hline França & - & - & - & - & - & - & - & - & 1 & - & 2 & - & 3 \\
\hline Hungria & - & - & - & - & - & - & 1 & - & - & - & - & - & 1 \\
\hline Inglaterra & - & 1 & - & - & - & - & - & - & - & - & - & - & 1 \\
\hline Japão & - & - & - & 1 & - & - & - & - & - & - & - & - & 1 \\
\hline Marrocos & 1 & - & - & - & - & - & - & - & - & - & - & - & 1 \\
\hline Países Baixos & 1 & - & - & - & - & - & - & - & - & - & - & - & 1 \\
\hline Peru & - & - & - & - & - & - & - & - & 1 & - & - & - & 1 \\
\hline Polônia & - & - & - & - & - & - & - & - & - & - & 1 & - & 1 \\
\hline Porto Rico & - & - & 1 & - & - & - & - & - & - & - & - & - & 1 \\
\hline Portugal & - & 1 & - & - & - & - & - & 2 & - & - & - & - & 3 \\
\hline Senegal & - & - & - & - & - & - & - & - & - & - & 1 & - & 1 \\
\hline Suíça & - & - & - & 1 & - & - & - & - & - & - & - & - & 1 \\
\hline União Soviética & - & 1 & - & - & - & - & - & - & - & - & - & - & 1 \\
\hline Uruguai & - & - & - & - & - & - & 1 & 1 & - & - & 1 & - & 3 \\
\hline Zimbábue & - & 1 & - & - & - & - & - & - & - & - & - & - & 1 \\
\hline Subtotal/Total & 6 & 5 & 3 & 2 & 1 & 3 & 3 & 8 & 8 & 1 & 7 & 2 & 49 \\
\hline
\end{tabular}

Fonte: Formulários de solicitação de pesquisa arquivados na Seção de Arquivo Histórico do Itamaraty em Brasília. 


\section{Notas}

1 Carta do Barão do Rio Branco, datada de Berlim, em 7 de agosto de 1902. Manuscrito do Arquivo Histórico do Itamaraty (RJ).

2 A legislação vigente não usa o termo secreto-exclusivo, mas sim ultra-secreto, portanto, o seu equivalente. A discussão sobre a legislação de acesso aos documentos sigilosos será feita mais adiante.

3 Regulamentado pelo Decreto $\mathrm{N}^{\circ} 2.134$, de 24/01/1997. Publicado no Diário Oficial da União em 27 de janeiro de 1997.

$4 \quad$ Existem ainda outras espécies de documentos produzidos pelo Ministério ou afetos diretamente a ele e que podem ser divididos em seis categorias: Correspondência de Uso Interno (OfícioVerbal, Despacho, Telegrama, Despacho telegráfico, Fax, Memorandum, Minimemo, Informação Interna e o Guia de Mensagem e Documentação), Correspondência Assinada (Carta de Chancelaria, Carta de Gabinete, Exposição de Motivos, Informação ao Presidente da República, Nota, Aviso, Ofício e Carta), Correspondência Não-Assinada [Verbal] (Nota-Verbal), Circulares (Circular-Postal, Circular-Telegráfica, Nota-Circular), Expedientes do MRE (Boletim de Serviço, Texto de Serviço e Instrução de Serviço) e Outros Tipos de Expediente - que podem ser afetos ao Ministério (Mensagem, Portaria, Decreto e Aide-Mémoire). Boa parte destes documentos, no entanto, diz mais respeito aos assuntos da burocracia interna do Ministério, envolvendo assuntos meramente administrativos e que são geralmente descartados, não compondo o Arquivo Histórico.

5 Doravante, as iniciais MRE serão usadas como abreviação para Ministério das Relações Exteriores.

6 Sobre o sistema de classificação decimal que era empregado pelo Itamaraty ver: MINISTÉRIO DAS RELAÇÕES EXTERIORES. Índice Decimal para a Classificação da Correspondência ( $v$ 1). Rio de Janeiro: Imprensa Nacional, 1934.

7 MINISTÉRIO DAS RELAÇÕES EXTERIORES. Manual de Classificação, Indexação, Distribuição e Arquivo. Brasília: MRE, 1994, p. 103.

$8 \quad$ Ibid, p.10.

9 Um documento pode ser desclassificado ou reclassificado pela Comissão. No primeiro caso, geralmente o documento é liberado para consulta pública. No segundo, pode-se reduzir o grau de sigilo ou mesmo elevá-lo, dependendo do entendimento da Comissão. O mais comum, naturalmente, é a desclassificação de documentos.

10 Denomina-se o arquivo do Rio de Janeiro como Arquivo Histórico do Itamaraty. O de Brasília é designado como Arquivo do Ministério das Relações Exteriores. De acordo com o RISE/1987 (Regimento Interno da Secretaria de Estado das Relações Exteriores) “o acervo de documentos datados a partir de 1970 será guardado no Setor de Arquivo Permanente em Brasília e o anterior àquela data, no Setor de Arquivo Histórico no Rio de Janeiro, sob a orientação e coordenação da Seção de Arquivo Histórico". Embora haja tal determinação, o acervo documental do Arquivo do Ministério das Relações Exteriores contém documentos de natureza sigilosa, os quais remontam aos anos 30, mas com ênfase de 1949 em diante. Da mesma forma, a documentação ostensiva, a partir de 1959/1960, encontra-se em Brasília. Sobre o RISE, ver: BRASIL. Ministério das Relações Exteriores. MRE - Serviço Exterior e Organização Básica. Brasília: SEMOR/MRE, 1987.

11 José Honório Rodrigues, por exemplo, apontava as dificuldades do estudo de eventos contemporâneos assinalando, dentre outras, justamente a dificuldade de acesso à documentação no Brasil. Citado em: “A Traição Inconstitucional”. Rio de Janeiro, Tribuna da Imprensa, 01/ 02/1989. Também o historiador Hélio Silva, referindo-se especificamente ao arquivo do Itamaraty, criticava o Ministério por manter uma prática muito restritiva de acesso à documentação, citando inclusive o seu próprio testemunho diante das dificuldades por ele encontradas quando 
escreveu sobre a Segunda Guerra Mundial. De acordo com o Jornal do Brasil, apesar da amizade do historiador com o Ministro Abreu Sodré - o que lhe teria facilitado o acesso a alguns documentos, porém não a todos -, aquele somente obteve as informações que desejava sobre o torpedeamento de navios mercantes brasileiros através de um professor alemão, que lhe franqueou os relatórios dos comandantes dos submarinos alemães que atuaram nas costas do Brasil. É interessante notar que, poucos anos após a denegação do pedido do historiador Hélio Silva, o pesquisador norte-americano Stanley Hilton obteve autorização para ver toda a documentação referente à participação do Brasil na Segunda Guerra Mundial, inclusive com respeito à atuação da espionagem alemã no Brasil, que resultou no livro Suástica sobre o Brasil. Sobre o depoimento de Hélio Silva, ver: "Itamaraty facilitará o acesso a arquivo, mas esconderá documentos". Rio de Janeiro, Jornal do Brasil, 29/01/1989.

12 No que diz respeito a esse assunto, existem no arquivo do Itamaraty documentos em abundância, tais como: Relatórios sobre o movimento comunista em regiões específicas do mundo (América Latina, Ásia e África, por exemplo), Relatórios sobre atividades comunistas em determinados países que interessavam mais diretamente ao Brasil (Uruguai, Bolívia e Argentina, por exemplo), Informes sobre Instituições Internacionais que suposta ou oficialmente tinham ligações com o movimento comunista internacional, Informes sobre a atuação de estrangeiros ligados a Partidos Comunistas que viviam no Brasil, Informes sobre as atividades de brasileiros no exterior suspeitos de atividades esquerdistas (exilados, estudantes ou outros), Informes repassados ao Itamaraty por outras agências nacionais ligadas à segurança do Estado ou à repressão, como DOPS, Ministérios militares (sobretudo o do Exército) e trocas de informações com Agências ou Embaixadas de outros países interessadas no combate ao movimento comunista.

BRASIL. Constituição (1988). Texto Constitucional de 5 de outubro de 1988 com as alterações adotadas pelas Emendas Constitucionais $n^{\circ}$ 1/92 a 4/93 e Emendas Constitucionais de Revisão $n^{\circ} 1$ a 6/94. Brasília: Senado Federal, Centro Gráfico, 1994. Respectivamente Capítulo I, Artigo $5^{\circ}$ XIV e XXXIII, p. 6 e 7.

14 Publicado no Diário Oficial da União de 25 de outubro de 1988.

15 Portaria $N^{\circ}$ 593, de 12 de Outubro de 1988, publicada no Diário Oficial da União de 25/10/ 1988.

16 Carta dirigida à Redação do jornal Folha de São Paulo, datada de Brasília, 03 de fevereiro de 1989, assinada pelo Embaixador Sérgio F. Guarischi Bath, presidente da Comissão Permanente de Revisão do Arquivo Histórico do Ministério das Relações Exteriores. Portaria N 594, de 12 de Outubro de 1988, publicada no Diário Oficial da União de 25 de outubro de 1988.

18 Ipsis litteris.

19 Idem.

20 "Itamaraty facilitará o acesso a arquivo, mas esconderá documentos". Jornal do Brasil, 28/01/ 1989.

21 "Professores são contra a proibição". Folha de São Paulo, 02/02/1989. A resposta aos duros termos colocados pela professora Tucci Carneiro veio na carta que o Presidente da Comissão Permanente, Embaixador Sérgio Bath, enviou para o jornal Folha de São Paulo. Nessa carta, o Embaixador argumentava que "o prazo maior exigido para a liberação de documentos relativos à vida particular das pessoas não deveria servir para proteger documentos de relevância pública, mas só aqueles que incidam exclusivamente no terreno da 'intimidade, a vida privada, a honra e a imagem das pessoas', que a Constituição vigente declara invioláveis”. Carta dirigida à Redação do jornal Folha de São Paulo, datada de Brasília, 03 de fevereiro de 1989 e assinada pelo Embaixador Sérgio F. Guarischi Bath, Presidente da Comissão Permanente de Revisão do Arquivo Histórico do Ministério das Relações Exteriores.

22 Neste caso, o critério para acesso passa pela análise da solicitação do pesquisador por parte do funcionário do Itamaraty encarregado da chefia da DCA (Divisão de Comunicações e Arquivo). 
Eventualmente, em se tratando de tema polêmico, o pedido é encaminhado para instâncias superiores, o que geralmente significa análise por parte da chefia do DCD (Departamento de Comunicações e Documentação), ou até mesmo pela área política do Ministério.

Portaria de 30 de setembro de 1992 do Gabinete do Ministro de Estado das Relações Exteriores (Celso Lafer). Publicada no Diário Oficial da União de 01 de outubro de 1992.

Idem, ibidem. Os primeiros membros nomeados para a Comissão foram: Embaixador João Hermes Pereira de Araújo (Presidente), Embaixador Sérgio Bath, Embaixador Gelson Fonseca Júnior, Embaixador Synesio Sampaio Goes Filho, Professor Celso Lafer, Professor Marcelo Paiva de Abreu, Doutora Celina do Amaral Peixoto. Cf. Portaria de 7 de janeiro de 1993, Gabinete do Ministro de Estado das Relações Exteriores, publicada no Diário Oficial da União de 8 de janeiro de 1993. Como a Portaria de criação da Comissão de Estudos de História Diplomática estabelecia um mandato de três anos e permitia a recondução dos membros por mais um período, em 04 de abril de 1996 foi emitida outra Portaria de nomeação, havendo somente duas substituições, as dos Embaixadores Gelson Fonseca Júnior, pelo Embaixador João Clemente Baena Soares, e Synesio Sampaio Goes Filho, pelo Embaixador Geraldo Holanda Cavalcanti. Portaria de 4 de abril de 1996, Gabinete do Ministro de Estado das Relações Exteriores.

Lei $\mathrm{N}^{\circ} 8.159$, de 08 de janeiro de 1991. ("Dispõe sobre a política nacional de arquivos públicos e privados e dá outras providências”.)

26 Portaria de 27 de agosto de 1992, assinada pelo Ministro Celso Lafer.

27 Observe-se o caráter vago e impreciso estipulado pela lei com relação à possibilidade de liberação de documentos por parte dos herdeiros do titular. Não está designado quais herdeiros teriam o poder de autorizar a consulta, o que pode provocar, por exemplo, controvérsias no âmbito familiar e dificultar a decisão de liberação documental por parte do responsável pela guarda dos documentos.

28 Decreto $\mathrm{N}^{\circ} 2.134$, de 24/01/1997. Publicado no Diário Oficial da União em 27 de janeiro de 1997. É esta a legislação em vigor.

29 Idem, ibidem, artigo 20. Note-se que os documentos classificados como "ostensivos" não apresentam caráter sigiloso, portanto não constam desta relação.

$30 \quad$ Idem, ibidem. Artigos 28 e 29.

31 Esta documentação encontra-se na Seção do Arquivo Histórico do Ministério das Relações Exteriores, em Brasília.

32 Ver Quadro 1 anexo com a relação completa dos países estudados.

33 A documentação consular é muito interessante, sobretudo para quem deseja investigar temas que escapem às tradicionais análises das relações políticas e econômicas. Neste tipo de documentação, o pesquisador irá deparar-se, entre outros, com documentos que retratam problemas comuns no cotidiano dos brasileiros no exterior, pedidos de vistos, informações sobre contrabando e, no caso dos consulados nas regiões fronteiriças, a realidade destas fronteiras. É preciso considerar também que, em alguns países, na ausência de Embaixadas ou legações, era o consulado que desempenhava a missão de manter a Chancelaria brasileira informada sobre a conjuntura do país, assim como se responsabilizava pelos assuntos comerciais.

34 Um balanço da produção historiográfica brasileira nos anos oitenta pode ser encontrado em: FICO, Carlos \& POLITO, Ronald. A História no Brasil (1980-1989): elementos para uma avaliação historiográfica. Ouro Preto: Ed. da UFOP, 1992.

35 Dentre a produção dos autores relacionados, destaca-se: CERVO, Amado L. As relações históricas entre o Brasil e a Itália; o papel da diplomacia. Brasília: Editora da Universidade de Brasília, 1992. CERVO, Amado L. \& BUENO, Clodoaldo. História da política exterior do Brasil. São Paulo: Ática, 1992. BUENO, Clodoaldo. A República e sua Política Exterior (1889 a 1902). Brasília: IPRI, 1996. MONIZ BANDEIRA, L. A. Brasil-Estados Unidos; a rivalidade emergente (1950-1988). Rio de Janeiro: Civilização Brasileira, 1989. MONIZ BANDEIRA, L. A . Presença 
dos Estados Unidos no Brasil; dois séculos de história. Rio de Janeiro: Civilização Brasileira, 1973. MOURA, Gerson. Autonomia na Dependência. Rio de Janeiro: Nova Fronteira, 1980. MOURA, Gerson. Sucessos e Ilusões; relações internacionais do Brasil durante e após a Segunda Guerra Mundial. Rio de Janeiro: Fundação Getúlio Vargas, 1991. SARAIVA, José Flávio Sombra. O lugar da África; a dimensão Atlântica da diplomacia brasileira (de 1946 a nossos dias). Brasília: Editora da Universidade de Brasília, 1996. RODRIGUES, José Honório. Interesse Nacional e Política Externa. Rio de Janeiro: Civilização Brasileira, 1966.

\section{Resumo}

Este artigo versa sobre a pesquisa histórica no arquivo do Itamaraty. Analisando a estrutura do Arquivo, a evolução das regras de acesso aos documentos diplomáticos brasileiros e as pesquisas nele efetuadas entre 1987-1998, o autor aponta que a Constituição de 1988 operou significativas mudanças no que concerne ao acesso à documentação contida no Arquivo, facilitando e estimulando novas pesquisas no campo da história das relações internacionais do Brasil.

\section{Abstract}

This article deals about historical research at Itamaraty's archive. By analyzing the structure of the archive, the evolution of the rules regarding the access to Brazilian diplomatic documents and the researches occurred in that archive during the period of 1987 to 1998 , the author argues that the Brazilian 1988 Constitution not only changed the rules of access to the documentation kept in the archive but also facilitated and stimulated researches about history of Brazilian international relations.

Palavras-chave: Arquivo Histórico do Itamaraty. Pesquisa Histórica. Legislação. Key-words: Itamaraty's Archive. Historical Researches. Legislation. 